Trinity University

Digital Commons @ Trinity

Sociology \& Anthropology Faculty Research

Sociology and Anthropology Department

$1-2004$

\title{
Models of Cosmic Order: Physical Expression of Sacred Space Among the Ancient Maya
}

Jennifer P. Mathews

Trinity University, jmathews@trinity.edu

J. F. Garber

Follow this and additional works at: https://digitalcommons.trinity.edu/socanthro_faculty

Part of the Anthropology Commons, and the Sociology Commons

\section{Repository Citation}

Mathews, J. P., \& Garber, J. F. (2004). Models of cosmic order: Physical expression of sacred space among the ancient Maya. Ancient Mesoamerica, 15(1), 49-59. doi: 10.1017/S0956536104151031

This Article is brought to you for free and open access by the Sociology and Anthropology Department at Digital Commons @ Trinity. It has been accepted for inclusion in Sociology \& Anthropology Faculty Research by an authorized administrator of Digital Commons @ Trinity. For more information, please contact jcostanz@trinity.edu. 


\title{
MODELS OF COSMIC ORDER
}

\section{Physical expression of sacred space among the ancient Maya}

\author{
Jennifer P. Mathews ${ }^{\mathrm{a}}$ and James F. Garber ${ }^{\mathrm{b}}$ \\ aDepartment of Sociology and Anthropology, Trinity University, One Trinity Place, San Antonio, TX 78212, USA

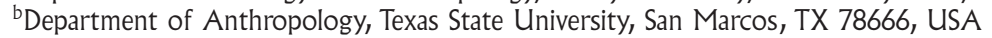

\begin{abstract}
The archaeological record, as well as written texts, oral traditions, and iconographic representations, express the Maya perception of cosmic order, including the concepts of quadripartite division and layered cosmos. The ritual act of portioning and layering created spatial order and was used to organize everything from the heavens to the layout of altars. These acts were also metaphors for world creation, world order, and establishing the center as a position of power and authority. This article examines the articulations of these concepts from the level of caches to the level of regions from the past and present in an attempt to understand these ancient perceptions. We emphasize that basic organizational notions of the cosmos permeate all societal levels and argue that scholars should expand their focus to include how the sacred landscape and its related ideology were reproduced in the lives of everyday people.
\end{abstract}

\section{THE CONCEPT OF COSMIC ORDER}

The configuration of the built landscape is clearly influenced by environmental factors such as climate and proximity to water, arable land, and a variety of resources (Fedick 1994). Nevertheless, it is equally important to consider the impact of the concepts of worldview and ideology. When examining factors that shape the built environment there is a tendency to focus on the more obvious configuration of monumental architecture and overall site layout. However, the same principles of organization are found at all levels of society (elite and non-elite) and are evident in a variety of more subtle portions of the built environment as well, including caches, altars, buildings, tombs, milpas, and plazuelas.

\section{Quadripartite Partitioning and Layering}

Several investigators have noted the Maya perception of world order (Ashmore 1991; Chase and Chase 1998; Coggins 1980; Freidel et al. 1993; Girard 1948; Guderjan 2004; Houston 1998; McAnany 1998; Paxton 2001; Tedlock 1985; Thompson 1966, 1970). This perception includes a horizontal division of the world into four quarters (and the center); a vertical division of the underworld into nine layers; and a division of the upperworld into 13 layers. The Maya perceived the sky as being held up by the four Bacabs set at the sides of the world, and often a ceiba tree marked the center. Equally important is the association of color and direction: red in the east, white in the north, black in the west, yellow in the south, and green in the center. Several gods of the Maya pan-

E-mail correspondence to: jmathews@trinity.edu theon occurred in groups of four or alternatively had four aspects, each associated with a direction and color. The four Chacs, one at each side of the world, serve as a prime example (Thompson 1966:225-226, 1970:169, 195-196; see also Paxton 2001:15-29).

Furthermore, the partitioning of the universe in terms of geographic areas and their associations is a reflection of quadripartite division, as seen in the Postclassic manuscripts of Mesoamerica. Eduard Seler (1901-1902) was one of the first scholars to explain the ritual and cyclical calendars found in late Maya books and recognized that these diagrams referred to the four quarters of the world and their associated birds, trees, colors, and deities. For example, in the Borgia Codex (Diaz and Rodgers 1993:29), Plate 49 represents the eastern, or Maya, region, and is associated with ceiba trees, quetzal birds, jade, and the sun god-all aspects found in the eastern or Maya area (Byland 1993:xxvii; Karl Taube, personal communication 1998).

Clemency Coggins (1980) notes that the quadripartite motif is symbolic of cyclic completion, including the completion of solar cycles and calendrical cycles. Examples include the quartered Maya kin sign, representing the sun, as well as a day; the kan cross, appearing in creation scenes; the Lamat sign; and the zero or "completion" sign (Figure 1). The katun cycle of 7,200 days is represented by a complex quadripartite glyph (Coggins 1980:728). In addition, quadripartite partitioning is a metaphor for creation. In the Popol Vuh, the Quiche Maya story of creation, the world had been created, destroyed, and re-created three times before the present creation. In the present, or fourth creation, the Maize God was brought back to life by his twin sons and was the principal actor of this creation (Freidel et al. 1993:284; Taube 1993:67; Tedlock 1985:159). Similar creation stories, or components of the creation story, can also be found in hieroglyphic texts at Chichen 


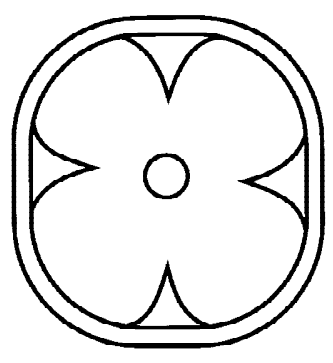

a

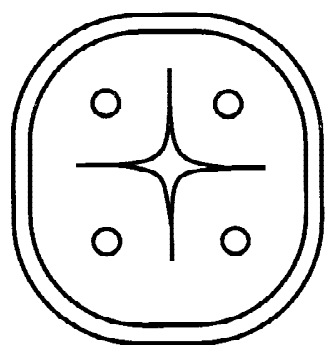

$\mathrm{c}$
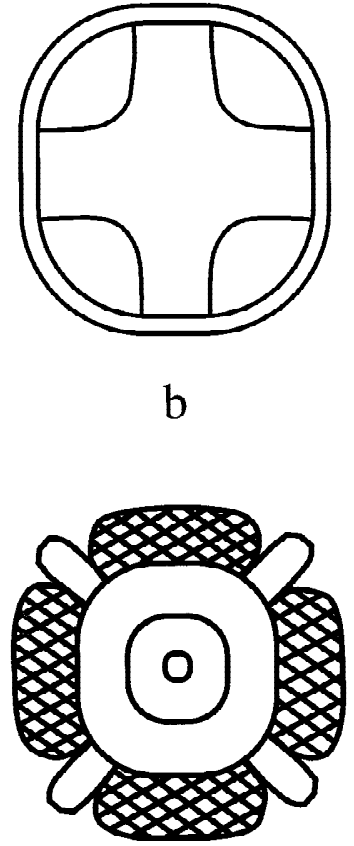

d
Figure 1. Maya quadripartite glyphs/signs: (a) Kin; (b) Kan; (c) Lamat; and (d) zero or "completion."

Itza, Coba, Palenque, Quiriqua, and Seibal, and on numerous polychrome vases of the Classic period (Coe 1978; Freidel et al. 1993; Reents-Budet 1994; Schele and Mathews 1999).

The resurrected father of the Hero Twins appears as the Maize God and sets out to complete the creation of the universe by staking out a house. This house defines the four sides and the four corners of the universe. The concept of partitioning is a critical component to a wide range of Maya ritual, as it is a metaphor for creation and thus is used as an invocation to employ a supernatural involvement at the initiation of a wide range of activities. The Maya reenact creation through the partitioning event when they create an altar with each corner representing a corner of the universe and the cross as a representation of the axis mundi. Just as the supernatural forces were present at the moment of creation, a reenactment of the original partitioning event will invoke these same supernatural forces for the event at hand and its participants (Girard 1966:33). At the center of the world is the axis mundi, the ceiba with its roots in Xibalba, the underworld, and its branches in the sky world, as depicted on Pacal's sarcophagus lid at Palenque. The trunk contains a $t z u k$ head to mark the quadripartite division, and the horizontal element of the tree, when represented in cross form, represents the ecliptic and/or the Milky Way as it stretches across the sky (Schele and Mathews 1999:114, 417-418).

The concept of four world quarters with a tree at the center goes back at least to Olmec times. F. Kent Reilly (1994) suggests that the iconography of two celts from Río Pesquero illustrate this concept of center and four corners (Figure 2). The central figure is the tree, the trilobed element on the crown is an indicator of sprouting vegetation, and the serpent bar is the ecliptic. The four world corners are marked by four rectangular elements. The Olmec examples illustrate the notion that the king, portrayed by the maize god, is the axis mundi at the center, a vital sociopolitical and

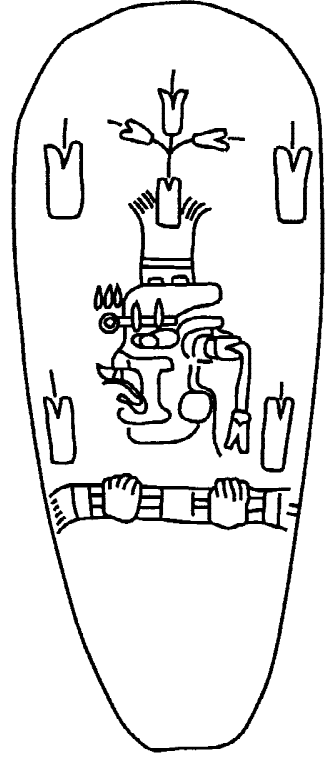

a

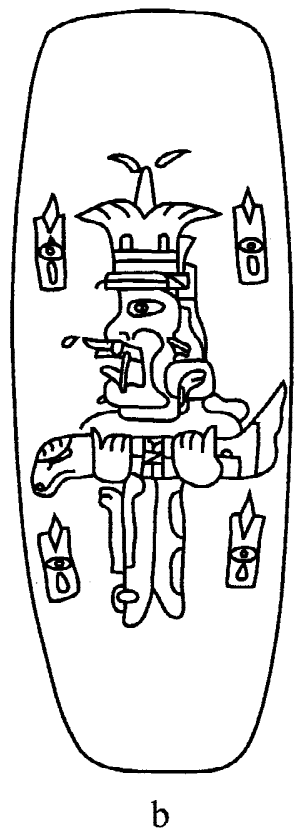

Figure 2. Incised celts from Río Pesquero (redrawn from Joralemon 1976:41).

religious statement of power and authority (Reilly 1990:38, 1994:83-84; Taube 1996:44).

Although a clear relationship is maintained between the cardinal directions and quadripartite division, the consistency in the directional associations is not always clear. Although the associations with the directions of the east and west in the post-Contactperiod books are relatively uniform, far more variance exists in the associations for north and south. Gordon Brotherson (1976:55) suggests that east and west directional symbolism are consistent because of their link to the path of the sun but that ancient Mesoamericans may have had very different concepts of north and south as compared with our Western concepts. In fact, it may have been that the only absolute directions were found where the sun rises and sets, and the points in between might refer to the local geographical north and south (Brotherson 1976:55; Coggins 1980:730). Wendy Ashmore (1991:201) sheds light on this issue in a model in which north may also be perceived as "up," with associations to sky and the celestial realm, and south as "down," with associations to the underworld.

A division of the world is also found in relation to lineages and ancestors associated with a particular place. The Ritual of the Four World Quarters in the Chilam Balam of Chumayel contains a listing of the first lineages and the names of the founding ancestors. "These were the four lineages from heaven, the substance of heaven, the moisture of heaven, the head-chiefs, the rulers of the land: Zacaal Puc, Hooltun Balam, Hochtun Poot, Ah Mex-Cuc Chan" (Roys 1967:147). William R. Coe (1965:112) suggests that this passage is a recapitulation of the Uayeb, or New Year ceremonies, in which named lineages from the four quarters of a settled place rotated their responsibilities for the fiestas and obligations associated with one of the four idols of the New Year. This suggests a regional dimension to lineages that, under ideal circumstances, would be associated with one of four quadrants of a settlement (Pollock et al. 1962). In fact, early chroniclers note that lineages were grouped in a quadripartite type of organization at Tah Itza and Acalan, Itzamkanac (Scholes and Roys 
1938:609-610) as well as at Mayapan (Proskouriakoff 1962:91, 135). The principle of a quadripartite division in reference to founding lineages is also found in the Popol Vuh, which names the four founding ancestors whose power and authority are expressed by their association of the ancestors with the four fierce jaguars: Balam Quitze, Balam Acab, Mahucutah, and Iqui Balam (Marcus 1993:126; McAnany 1995:27; Tedlock 1985:167-68).

The Tro-Cortesiano (Madrid) Codex depicts the partitioned organization of the universe (Figure 3). The world tree, rooted in Xibalba and its upper story piercing the heart of heaven, is at the center of the house or universe. Thus, when the Maya ritually acknowledge the center, corner, and sides of an altar, house, plazuela, milpa, or ceremonial center, they are reenacting the creation of the universe and positioning themselves at the center (Freidel et al. 1993:129-130). The Olmec examples mentioned earlier that place the king at the center as the world tree illustrate the sociopolitical importance of this ritual action (Reilly 1990:38, 1994:83-84; Taube 1996:44).

This discussion illustrates the Maya multilayered quadripartite universe and its associated concepts of creation, cosmic structure, cyclical completion, cardinal directions, lineages, gods, plants, and colors. Furthermore, the quadripartite division had sacred meaning for the ancient Maya. Susan Gillespie (2000:158-159) also notes that " $[t]$ he Maya see the universe as a series of concentric containers and materialize this functional imagery for themselves at the local level as a series of nested houses, reflecting the concentric principle of Mesoamerican sociocosmology that organizes all space." She argues that a village, a house, and an altar are all analogous, as their perimeters are all ritually created and mutually connected. The altar, as a symbolic house, is nested within an individual house, which is then nested with the village community, and so on (Gillespie 2000:158-159). These complex concepts were incorporated into the elite and non-elite built environment on a variety of scales, from simple features to intricate regional sociopolitical systems. The authors base the classifications used in this paper on these ideas of scale, although the four levels are their own constructs: Level One-altars and caches; Level Two-buildings, tombs, and milpas; Level Threeplazuelas and ceremonial centers; and Level Four-settlement systems and regions.

\section{EXAMPLES OF QUADRIPARTITE DIVISION AND VERTICAL LAYERING IN THE BUILT ENVIRONMENT}

\section{Level One-Altars and Caches}

The importance of partitioning is clearly shown in several Maya rituals in the ethnographic record. The Chorti Maya performed a ritual on February 8, which marks the beginning of their agricultural year (Girard 1966:33). The ritual begins with the placement
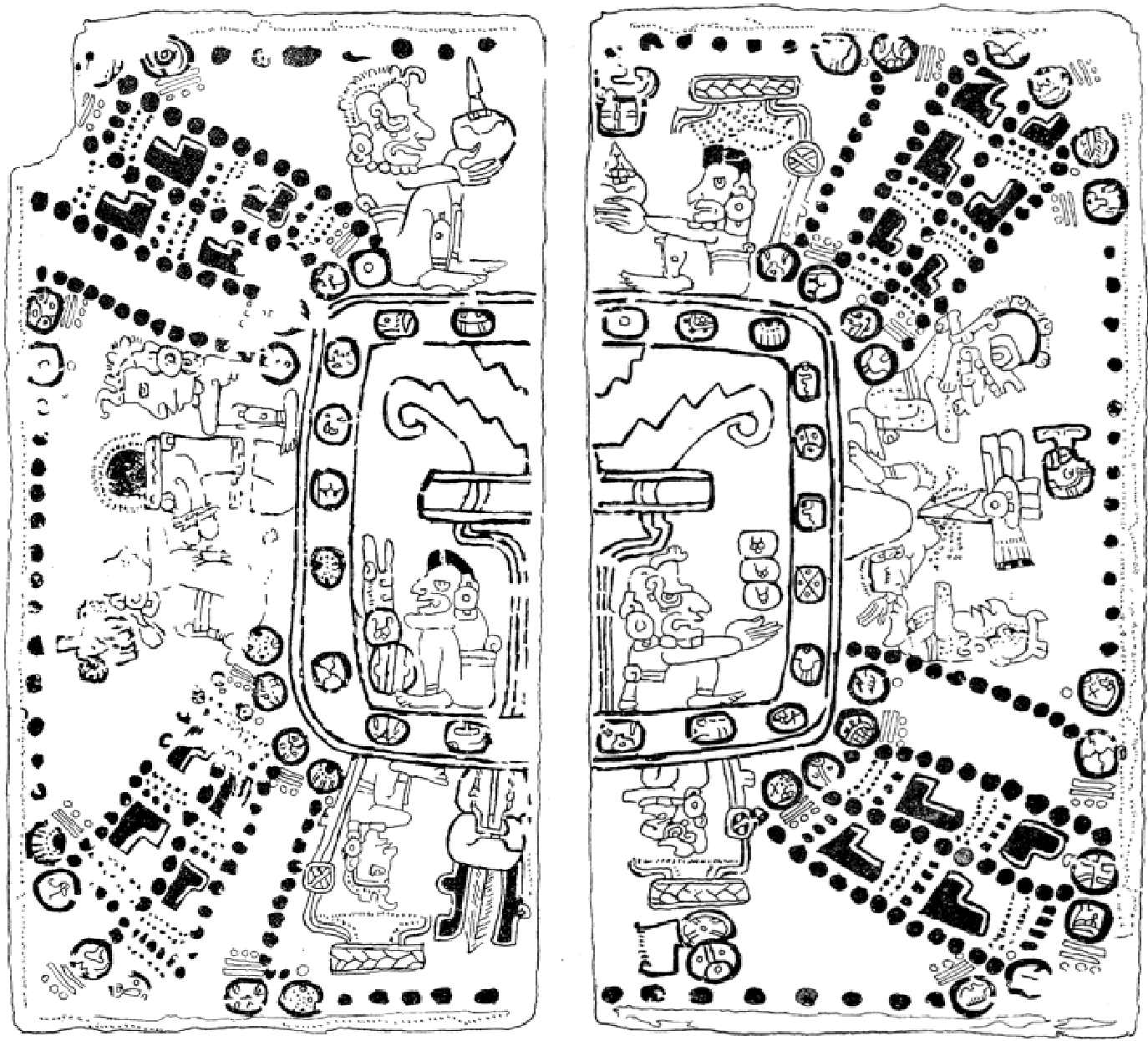

Figure 3. Codex Tro-Cortesiano (Villacorta and Villacorta 1930:374-376). 
of five stones on the altar table; one is placed at each corner, and a fifth is placed at the center. According to the Chorti, the corner positions represent solstice stations of sunrise and sunset and that this ritual is a reenactment of the creation of the world as performed by the gods.

On April 25, the Chorti perform a ritual to raise the sky and continue this ritual each night until the rains come. From a seated position, assistants at each corner of the altar simultaneously rise up to lift the sky (Girard 1966:33). J. Eric Thompson (1930) recorded an all-night renewal ceremony among the Mopan-speaking Maya of northern Belize. This ritual, like that of the Chorti, took place on February 8, at the beginning of their agricultural year. Early February was a time of heightened ritual activity in Classic times, as well (Thompson 1930:41-42). .

We can also see this pattern of partitioning in the placement of cache items and grave goods. Patricia McAnany describes a cache deposited below a Late Formative ancestor shrine at K'axob, Belize, that consisted of four vessels arranged in a quadripartite pattern. The arrangement of the bowls confirms (or creates) the centrality of this location in its association with the ancestors (McAnany 1995:104). In addition, ceramic vessels placed in ancestral shrines at K'axob were decorated with the quadripartite motif (McAnany 1995:57, Figures 2.16 and 2.17).

A similar quadripartite cache was recovered in the eastern mound of a Late Classic plazuela group at the site of Blackman Eddy, Belize (Garber et al. 1992:9; Garber et al. 1998:129-130). The eastern mound contained several deposits, suggesting its prominence as the focus of ritual activity within the plazuela group. Ritual deposits were not found in either of the other two mounds of the group. The concentration of ritual activity in the eastern mounds of Belize Valley plazuela groups occurred at other sites, as well: Floral Park (Glassman et al. 1995), Cahal Pech (Awe et al. 1992; Goldsmith 1993), and Baking Pot (Powis 1993). Eastern-focus mound groups appear to be a distinctive ceremonial tradition that was widely practiced in the Caracol area, the Peten at sites such as Tikal and Seibal, the upper Belize Valley, Quirigua, and Copan (Becker 1971, 1972; Chase 1993; Chase and Chase 1998; Harrison 1981:Figure 10.3; Jones and Sharer 1980; Laporte 1991, 1994; Laporte et al. 1989; Sharer et al. 1999; Tourtellot 1998).

The Blackman Eddy cache is interpreted as components of a New Year ceremony that contained destructive and subsequent regenerative aspects (Garber et al. 1998:130). The feature consisted of five whole vessels within a matrix of densely packed, heavily burned sherds. The volume of sherds could represent more than 100 vessels, although there was no evidence of in situ vessel breakage. Similar contemporary deposits were encountered at the nearby sites of Floral Park (Glassman et al. 1995:60) and Ontario Village (Garber et al. 1994:11). The Floral Park deposit was considerably more extensive and may represent more than 1,000 vessels. Both sites showed burning and heavy weathering in the sherd concentrations, and no in situ breakage of vessels was evident.

The unburned whole vessels of the Blackman Eddy cache deposit formed a quadripartite pattern oriented to the cardinal directions. Bowls were in the north, south, and west positions. A plate was in the eastern position, and an inverted plate was over the southern bowl. Obsidian lancets were recovered in the northern and southern bowls. Sharply pointed blades such as these were common items used in bloodletting rituals. Blood sacrifice and its symbolism were, and still are, an important aspect of Maya religion and were the means of activating portals to the underworld (Chase 1991:90; McGee 1990:88-89; Schele and Freidel 1990:68-
69, 222; Schele and Miller 1986:177-179; Tozzer 1966:113-114). Landa (Tozzer 1966:113-114) describes bloodletting rites associated with New Year ceremonies among the Yucatec Maya. Iconographic representations, such as Lord Pacal's sarcophagus lid at Palenque, depicting bloodletting, and associated events often portray the sacred world tree. Bloodletting paraphernalia are depicted at the base of the tree, or portal to the underworld. For example, a stingray spine is included with the Quadripartite God, a personified offering plate, found on Pacal's sarcophagus (Schele and Mathews 1999:113). Raising the world tree separated earth and sky, and the subsequent partitioning of the world into its four sides and four corners created the world form. Quadripartite positioning of the whole vessels is a symbolic reenactment of the creation partitioning.

The ethnohistoric and ethnographic literature provides additional clues to the meaning of these deposits. In his Relación, Landa described the rituals and activities associated with the first day of Pop, the initiation of the New Year in the 365-day year (Tozzer 1966). The New Year followed the Uayeb (five days of bad luck and apprehension following the Haab of 360 days). Landa describes the New Year preparation and celebration as one in which the entire community participated. This was a ritual of destruction and renewal or rebirth. Destructive actions preceded the establishment of order in the New Year. "To celebrate it with more solemnity, they renewed on this day all the objects that they made use of, such as plates, vessels, stools, mats and old clothes and the stuffs with which they wrapped up their idols. They swept out their houses, and the sweepings and the old utensils they threw out on the waste heap outside the town; and no one, even he in need of it, touched it" (Tozzer 1966:151-152). This ritual destruction involved mundane items analogous to those seen in the Belize Valley sherd concentrations, the great majority of which were utilitarian wares (Glassman et al. 1995:60; Garber et al. 1994:11).

In Momostenango, Guatemala, ritual leaders make a four-part ritual circuit to the positions that define the four corners of their world. At the center of their world is a wakibal, or "six-place" shrine, that has pits containing ritual fires and hundreds of broken ceramic vessels (Tedlock 1982:71). The pattern of this ritual circuit is a model of the world, as they perceive it. These examples reaffirm the quadripartite division of the universe and its association with directions, ancestors, and lifecycles. In addition, Maya burials occur frequently under house floors, a practice that continued into the Historic era. Within the previously noted easternfocus mound-group zone, burials are frequently, and sometimes exclusively, located in the eastern structure. Interments in eastern structures accumulatively added to the power of these locations and reaffirmed the association with ancestors.

While some caches symbolically represent the quadripartite division of the world, others illustrate the layered nature of the universe. One such cache was recovered from the eastern mound at Blackman Eddy (Garber et al. 1998:127-128). This dedicatory cache was placed on the surface of the underlying bedrock and initiated the platform's construction. Although this bedrock cache was the earliest artifactual evidence of ritual activity at this location, it was not the first ritual action. The lowermost construction fill did not overlie an old land surface. Rather, it was placed on leveled, clean bedrock that did not show weathering. The construction of a simple low platform of untrimmed limestone blocks did not structurally require a prepared foundation and probably represented a ritual cleansing prior to construction. The practice of preparing a "cleansed" ground surface before construction oc- 
curred at other locations at Blackman Eddy (Garber et al. 1998:127) and Floral Park (Glassman et al. 1995:63).

This initial cache was on the primary east-west axis of the mound and consisted of two lip-to-lip Early Classic bowls. The lower bowl contained a layer of white marl, nine large crude brown chert flakes, carbonized twigs, and a rodent skeleton (Figure 4). On the basis of their uniformity of color and texture, the flakes appear to be from the same core. The overlapping arrangement of the nine flakes formed a downward spiral and was partially embedded in the layer of white marl. The innermost flakes of the spiral were deeper in the layer than the outermost ones. The layer of carbonized sticks and the skeletal remains of a small rodent covered the spiral of flakes (Garber et al. 1998:127).

Recent studies propose that cached offerings reflect Maya concepts of world creation and the role of dedication in the animation or activation of sacred space (Freidel and Schele 1989:236; Freidel et al. 1993:244-46; Schele and Freidel 1990:121) and symbolic models of the cosmos (Chase and Chase 1998:303-304; Guderjan 2004; Joyce 1992). The artifacts represent sacred symbols in which supernatural powers reside and evoke the presence of those spirits through creation reenactment or cosmological modeling. Such offerings were vital in the establishment and maintenance of a structure's connection to ancestral spirits and supernatural forces.

The patterned position of the Blackman Eddy cache contents demonstrates intentional placement. The nine flakes of this cache represent a recurring spiritual theme associated with Maya ideology involving the number nine. This sacred number appears repeatedly in Maya architecture, caches, art, and calendrics and frequently represents the nine Lords of the Night or Underworld. Caches containing nine chert or obsidian flakes occur in sites throughout the lowlands (Coe 1959:83-84, 90, 93; Smith 1950:206, 208-210, 1972; Willey et al. 1965:449, Figure 281). Although the materials within this cache represent the low end of the quality continuum, they are the functional equivalents of more sumptuous examples such the nine elaborately chipped stone eccentrics recovered within a dedicatory cache at Copan (Fash 2001:100) or the nine imitation stingray spines found in a dedicatory cache at Tikal (Freidel et al. 1993:Figure 5.6a). .

Placed on a specially prepared surface, the Blackman Eddy cache represents the initial activation of what was to become the focal point of ritual for this residential plazuela group. Symbolic cosmological layering is evident within the cache. The marl layer represents the clean bedrock base beneath the structure. The nine flakes represent the nine Lords of the Night or Underworld. The spiral pattern indicates downward movement, resulting in a portal to the supernatural world. Small rodents play a role in Maya mythology as beings of the underworld, such as life forms of prior creations and middle-world beings that can descend below the surface of the earth (Pohl 1983:85). The symbolism indicated by the contents of the cache suggests that it functioned as a portal to the underworld. The nine chert flakes, like the nine imitation stingray spine bloodletters from the Tikal cache, are the instruments that activated the portal and allowed supernatural power to flow into the structure. Once activated, this portal spiritually ensouled the building. Just as a person must receive a soul, so must a building - whether it is a temple, a palace, or simply a common house (Freidel et al. 1993:234). This is accomplished through the construction of a symbolic representation of the universe. Layered caches can represent the vertical dimension of the universe and the portals associated with travel between the layers, whereas caches with a quadripartite configuration emphasize the horizontal configuration of the world and its creation.

\section{Level Two-Buildings, Tombs, and Milpas}

At Level Two, there are several examples of structures with four stairways mirroring the cardinal directions. Examples include Structure E-VII Sub at Uaxactun; the four-way ramp structure where Sacbe 1 and Sacbe 3 intersect at Coba; and the Castillo at Chichen Itza. This pattern has been interpreted as a representation of the Maya sign for cyclic completion and a model of the quadripartite symbol for completion (Coggins 1980:731-732). A less obvious example is the Temple of the Four Directions at Punta Islet on the Cozumel Island. While it does not have stairways aligned to the cardinal directions, it does have design elements that do align in this way. On the roof of this well-preserved temple is a masonry cone-shaped element with an alignment of snail shells and arrowhead-shaped stones inserted in the masonry. These decorations are located on the four corners and the midpoints and are aligned with the doorways below, clearly showing directional symbolism (Sanders 1955:193).

Tomb 12 at Río Azul in Guatemala shows explicit directional symbolism, as it is marked with cardinal directions on the four

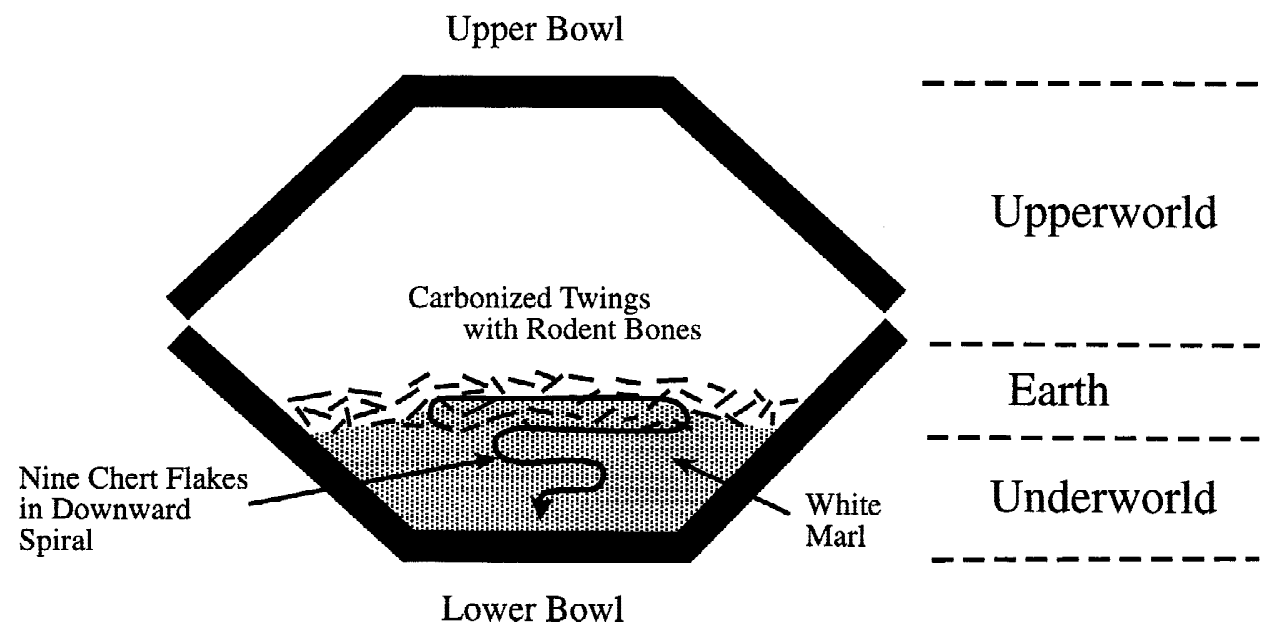

Figure 4. Blackman Eddy, section view of BE Cache 7, Structure 1C. 

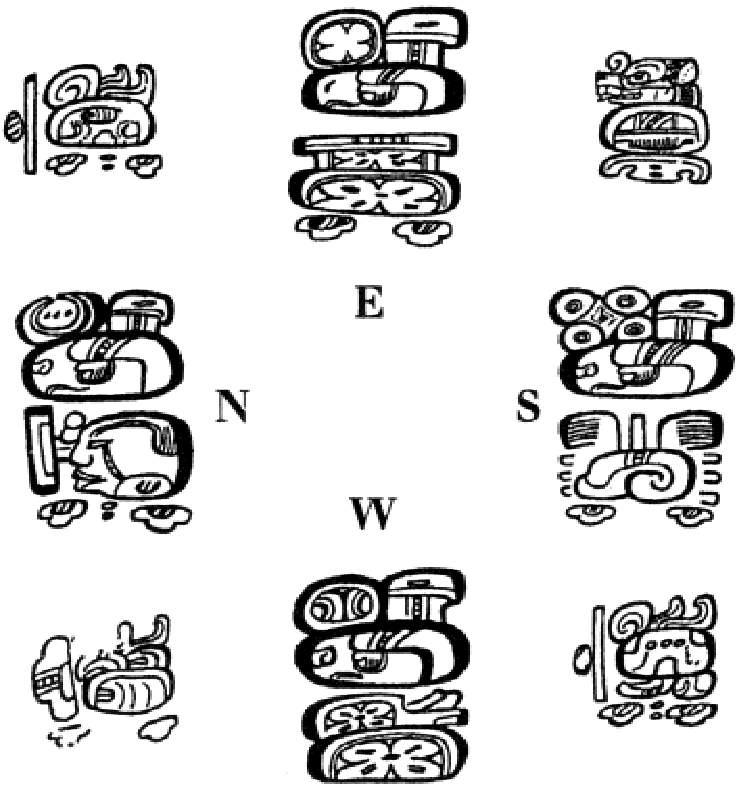

Figure 5. Painted glyphs from tomb at Río Azul, Guatemala (drawing courtesy of David Stuart).

corresponding walls and the inter-cardinal directions in the corners (Adams 1986:442; Figure 5). Linda Schele has read the glyph in the northeast corner as "raised up ocean place" and notes a contrast to a similar glyph from Palenque that reads, "lying down ocean place" (Freidel et al. 1993:418-419). This corner, or any other, could be "raised up" or "lying down" depending on where one was in the creation sequence-in other words, before or after the raising of the sky and prior to the partitioning of the world. The glyph for east is associated with the kin glyph, referring to "day" or "light"; the glyph for west is associated with akbal or "darkness"; the glyph for south is a Venus glyph, which has male associations; and the north glyph is linked with the feminine moon. On the east-west axis, these directions correspond to the endless solar cycle of life and death, and on the north-south axis they correspond to the maintenance of the solar cycle by human and divine agents (Ashmore 1991:212; Coggins 1980:731). The position of the dead king in the center of the tomb is a symbolic statement of power and authority as well as a link to ancestors and gods.

Quadripartite division is also seen in the non-elite Maya architecture of the ethnographic present. In his ethnography of the $\mathrm{Zi}$ nacanteco, Evon Vogt (1976) describes the house and field as models of the universe. The universe has gods who support the four directional corners and have an axis mundi at the center. Modern houses have corresponding posts in the corners and threestone fire hearths representing the center (Vogt 1976:58). In addition, Vogt describes rituals corresponding to these beliefs, including an indoor ritual conducted during the construction of a new house. A rope is placed from the peak at the center of the house, and four chickens (one for each corner) are tied to it. They are then killed, and their heads are buried in the center of the floor. Once the house is completed, a black rooster is killed and buried in the middle of the house in a center grave, with the head placed toward the rising sun (Vogt 1976:52).
Charles Wisdom also notes that, although the milpa is consistently thought of as being square, it cannot always be in reality because the cultivable land is hilly and covered with stones and boulders. As a correction factor when a new milpa is laid out, a coral tree is planted at each of the four corners to serve as boundary markers (Wisdom 1940:40). Similarly, Robert Redfield discusses the ritual offerings by agriculturalists in milpas, which consist of four bowls of cornmeal in water, placed in the four corners of the milpa, and a fifth placed in the central position. These bowls, like the coral trees, are positioned to represent the ideal square of the cornfield (Redfield 1941:120).

This type of quadripartite division is seen in the archaeological record of non-elite architecture, as well. Survey in the upper River Belize Valley by Scott Fedick (1994) revealed small rectangular plots defined by rock alignments in quadripartite arrangements (Figure 6). These alignments are immediately adjacent to residential units and may have been used for intensive vegetable gardening, property divisions, or raised walkways (Fedick 1994:121). Specifically, two sites located $1 \mathrm{~km}$ from each other consist of walls marking a cross within an agricultural field with a large mound in the center (Scott L. Fedick, personal communication 2002).

\section{Level Three-Plazuelas and Ceremonial Centers}

Ashmore (1991) presents a model of architectural arrangement and cosmological symbolism that can be used to describe the configuration and meaning of architectural units that make up plazuelas, plazas, and ceremonial centers. The most illustrative and perhaps explicit expression of this model is the Twin Pyramid Complexes at Tikal. The pyramids on the east and west represent the path of the sun, and in the north end of the complex is an

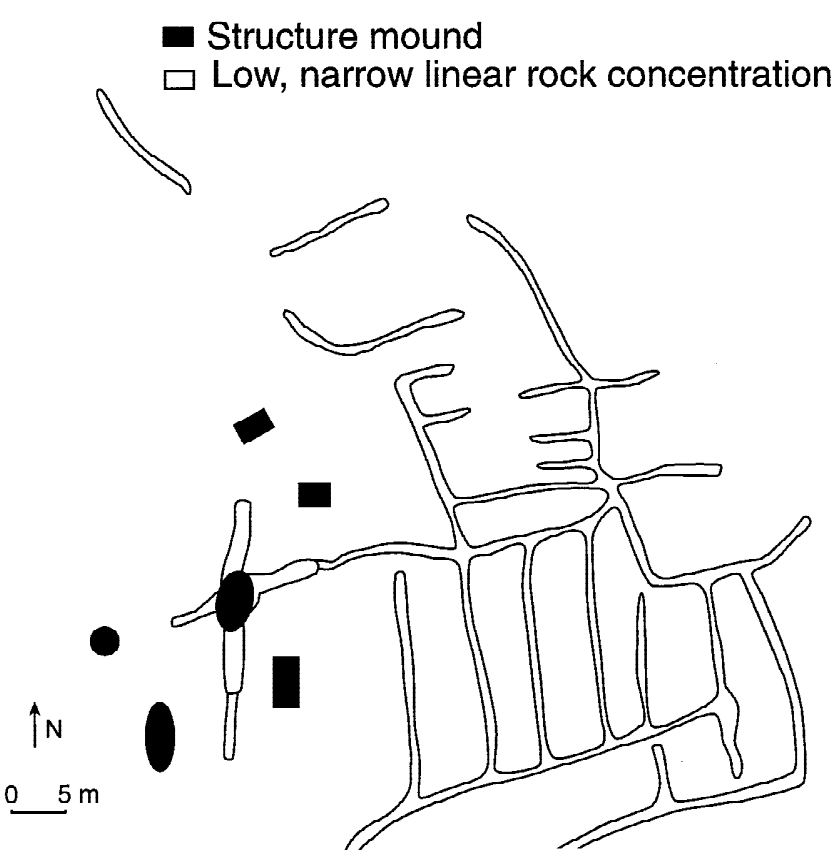

Figure 6. Field walls arranged in quadripartite cross (figure courtesy of Scott L. Fedick). 
unroofed, walled enclosure containing a portrait stela and associated altar. On the south is a palace with nine doors, representing the Nine Lords of the Night. Because of its association with the underworld, this southern position is perceived as "down," and the north enclosure represents "up" or sky. The placement of the stela portrait thus places the ruler in the sky position of celestial authority and power (Ashmore 1991:201; Coggins 1980:737). In addition, Ashmore (1991:202) uses this organizational principle and its associated symbolism to interpret the Great Plaza and North Acropolis at Tikal.

Like the configuration on the Río Pesquero celt discussed earlier, the ruler is placed in a position of power and authority. Although each identifies a different position of power and authority, the models are complementary, not contradictory. In the Río Pesquero case, the authority position is at the "center," a statement referring to creation and the resurrection of First Father as the Maize God (Reilly 1990:38-39, 1994:183, 1995:38; Taube 1996:44). In the Ashmore model (1991:201), the position of power and authority is "up," or celestial, a statement referring to cosmological structure after creation.

The directional associations expressed in the Ashmore model hold true in a general sense for several Maya ceremonial centers (Figure 7). For example, many ceremonial centers or plazas within ceremonial centers show "E-Group" configurations on the eastern side of the plaza. These are associated with horizon positions of the sun at the equinoxes and solstices. Although represented in a different way, both the east-west axis of the Twin Pyramid Complexes and the east-west axis of plazas with "E-Groups" are associated with the sun. The northern position at several sites has been shown to express ancestral and sky associations (Ashmore 1991:201; Garber and Reilly 1995; Houk 1996), and ballcourts (frequently in the central or southern portion of a site) have been shown to represent portals to the underworld or the underworld itself (Freidel et al. 1993:139, 350-355).

\section{Level Four-Settlement Systems and Regions}

Directional symbolism can be seen ethnographically, historically, and prehistorically in the layout of roads, or sacbeob. For example, in one of the small villages of the Chorti in Guatemala, seven roads led out of town, but only four were considered important and led out toward the cardinal directions (Wisdom 1940:421).

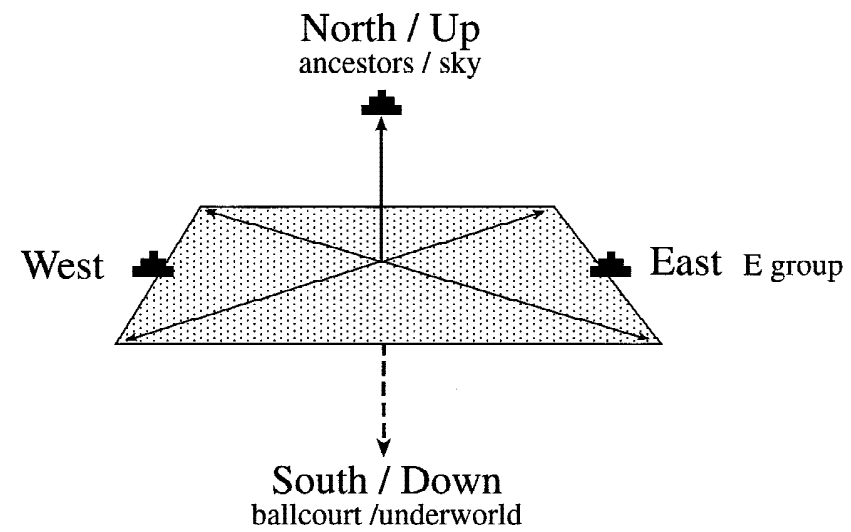

Figure 7. Diagram of directional symbolism at a Maya ceremonial center.
Each of these four roads had a cross at the point where it left the pueblo. This protected villagers from evil spirits and apparitions attempting to enter the town. A similar situation was documented by Redfield and Alfonso Villa-Rojas (1934:114) at Chan Kom in which crosses were placed at the four entrances representing the four corners of the pueblo. As with the Chorti village, there were three additional entrances that had no ritual significance and were not denoted with a cross.

We can also see the quadripartite pattern among the Maya at the time of Spanish contact. The Colonial writings of Landa note that every town in Yucatan had four entrances, each located at one of the cardinal directions. A hollow clay image of the god of the Uayeb days with the correct color association was made, carried to the entrance at the appropriate direction, and placed on one of the two stone heaps at the entrance. Ideally, there was a road leading in from each of the four cardinal points to the center of the community, implying that the town was divided into four quarters associated with the cardinal directions (Coe 1965:102; Tozzer 1966:135-140; Figure 8).

This same pattern is seen prehistorically in the Yucatan Peninsula, as well. The sacbeob at the sites of Ek Balam (Bey et al. 1997:239; Figure 2), Coba (Navarette et al. 1979:Figure 8), El Naranjal (Fedick and Taube 1995:14, see Figure 1.8) and T'isil (Mathews and Fedick 2002:4-5) radiate in four directions, mirroring the quadripartite motif (Figure 9). Although clearly defined at Ek Balam and Coba, the pattern at El Naranjal and T'isil are not fully confirmed in all directions. Sacbeob at T'isil have been located in the east and possibly in the northern position, while at El Naranjal they have been located in the northern and western positions, with indications that there is a road on the eastern side, as well. The preliminary research shows that this eastern road at El Naranjal may have had a regional connection that led inland all the way to the coast near Puerto Morelos (Fedick et al. 1995:129; Mathews 1998:180, 2001:2). Victor W. Von Hagen has also recognized this regional pattern. He states that the Spanish observed the site of Izamal as "a center of great pilgrimages: for which reason there had been made four roads running out to the four cardinal points which reached to all ends of land, Tabasco, Guatemala, Chiapas, so that today (1633) in many parts may be seen vestiges of those roads" (Von Hagen 1960:188).

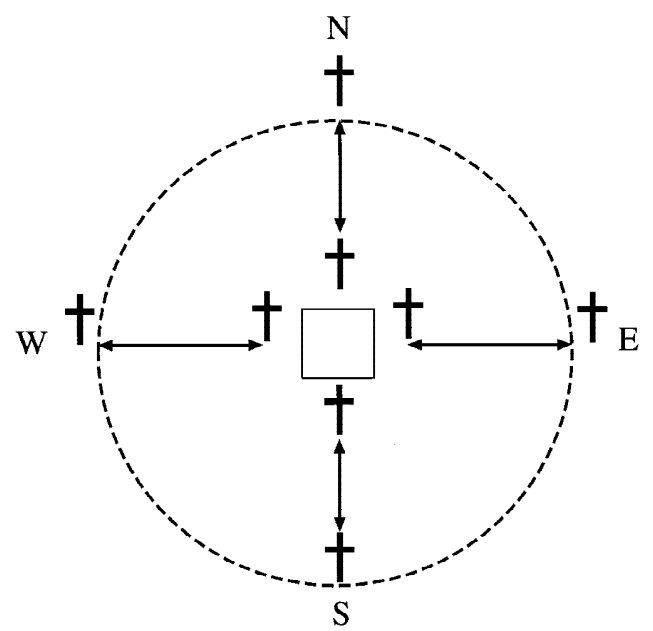

Figure 8. Town plan and locations of cross shrines. 


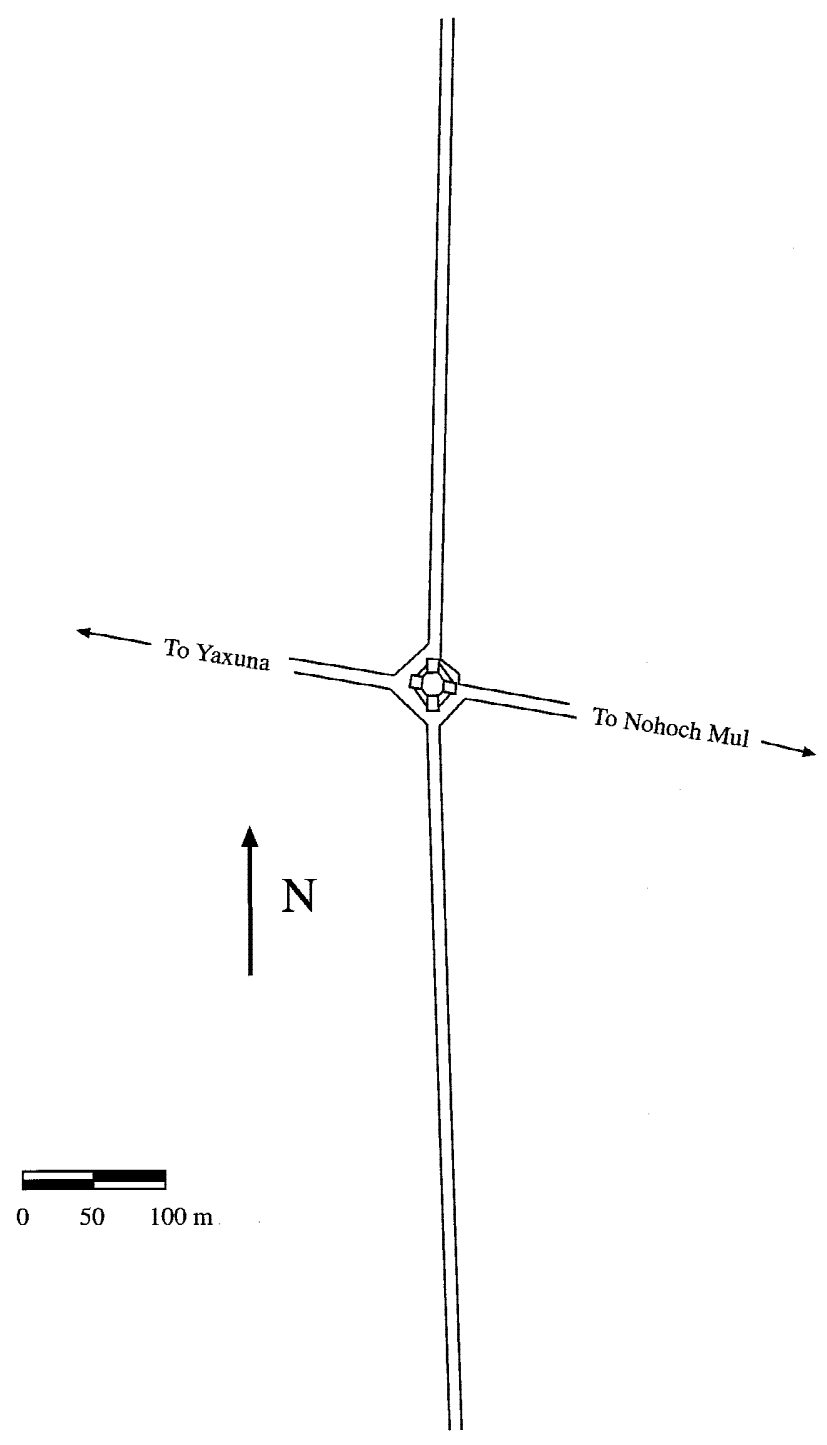

Figure 9. The intersection of Sacbe 1 and Sacbe 3 at Coba (redrawn from Navarette et al. 1979:Figure 8).

Joyce Marcus suggests that the Copan ruler 18 Rabbit viewed the four great dynasties mentioned on Stela A as the "four on high," representing the four quadrants of the lowland Maya world (Marcus 1973:912-913). It would have represented an ideal layout, not actual history or geography, in part because it listed only the Emblem Glyphs of Copan, Tikal, Calakmul, and Palenque. This was not because there were only four great cities, but because 18 Rabbit, the commissioner of the monument, felt they were the most powerful in each of the four quadrants of the Maya world in A.D. 731 (Marcus 1993:150).
This idealized geographic layout is also seen in the Colonialperiod documents of Yucatan. A circular map of northern Yucatan from the Chilam Balam of Chumayel placed west on the top and the capital of Tiho, or what is now Merida, in its center. Surrounding this are the major towns of the time, placed ideally in the four quadrants of the map. While this does not reflect the realities of the actual geography, it is clear that the Maya envisioned a large territory, such as the regional state of Yucatan, as circular with quadripartite divisions (Marcus 1993:128).

\section{CONCLUSIONS}

Quadripartite organization and vertical layering is a fundamental part of Maya ideology that arranges everything from the heavens to simple features. Quadripartite partitioning and vertical layering are both important components of the creation story and world order; thus, their re-creation served as an invocation to sanctify the utilization of space. As has been shown, this was done in the layout of caches, altars, buildings, tombs, milpas, plazuelas, villages, and ceremonial centers. This modeling, on any level, invokes the presence of the supernatural forces present at creation. The Maya initiate a wide range of activities with a ritual of partitioning as a means of creating spatial order. The ritual reenactment of creation connects the participants with the supernatural by opening a portal to the supernatural world through imitative magic. The concept was so important that it was even imposed on entire regions in an idealized form that did not always accurately reflect the actual geography.

The significance of any ritual deposit lies not in the material nature of its contents but, rather, in the symbolic nature of its deposition. This has important ramifications for our understanding of Maya social structure. For example, it appears that the ritual act of caching, and the concepts represented, was not one of the features that separated commoner from elite. For if the basic concepts of cosmos organization permeate all levels of society, then the ritual and ideological disparity between commoner and elite were not as great as some have suggested.

Elite contexts are characterized by finely made items of exotic materials. The materials from non-elite contexts are ordinary and mundane, yet they clearly served the same functions as their elite analogs. Thus, commoner and elite shared a belief in the symbolically represented ideas. These conceptions, with their roots extending at least to Olmec times, continue among modern-day Maya and are a testimony to the endurance and significance of concepts of space-concepts that survived periods of extreme social change. The Maya perceptions of how space is structured will in part determine how space is used. Explanations of ancient Maya sociopolitical systems have focused on carrying capacities of the environment, agricultural technology, and proximity to resources. If Mayanists are to understand the utilization of space, they must include in these models the views of how that space was perceived.

\section{RESUMEN}

Dos conceptos significantes en la ideología mesoamericana son la división del espacio en cuatro cuadrantes y el de capas verticales. Los mayas del pasado usaron estos ideas para organizar todo su mundo incluyendo todo en los cielos hasta los detalles más básicos de la vida cotidiana. La división en cuatro cuadrantes y los niveles de capas verticales son componentes impor- tantes de la historia de la creación y el orden del mundo, y siendo así, su recreación sirvieron como la invocación para sanctificar la utilización del espacio. Mientras que la mayoría de los especialistas han enfocado sus investigaciones en la manifestación o expresión de estos conceptos en, por ejemplo, el nivel del centro de un sitio mayor, es importante recordar que 
estos conceptos y expresiones de una creencia en el orden del mundo pueden demonstrarse en niveles modestos tambien, como el plano o el arreglo de los depositos rituales, altares, tumbas, milpas, plazas y asentamientos.

La utilización de este modelo, en cualquier nivel, invoca las fuerzas supernaturales que estuvieron presentes en la creación y representa una manera para que los maya pudieran crear orden espacial. Lo significancia de cualquier depósito ritual no se encuentra en los materiales contenidos, sino en la naturaleza simbólica de su deposición. Aunque los materiales de los depósitos en contextos que no representan la élite parecen mundanos en comparación con los bienes exóticos de los otros contextos que sí lo son, es evidente que, a pesar de las diferencias en los materiales los depósitos representando la élite hasta los que representan los más humildes en la sociedad sirvieron el mismo propósito. Eso tiene implicaciones importantes para nuestro entendimiento de la estructura social de los mayas. Si los conceptos básicos de la organización del cosmos penetran todos los niveles de la sociedad, entonces las diferencias ritualistas e ideológicas entre los plebeyos y la élite no fueron tan profundos como algunos han propuesto.

\section{ACKNOWLEDGMENTS}

We thank Wendy Ashmore, Scott Fedick, Tom Guderjan, Peter Harrison, Patricia McAnany, Kent Reilly, and Karl Taube for their helpful comments

\section{REFERENCES}

Adams, Richard E.W

1986 Rio Azul. National Geographic 169:420-451.

Ashmore, Wendy

1991 Site-Planning Principles and Concepts of Directionality Among the Ancient Maya. Latin American Antiquity 2(3):199-226.

Awe, Jaime, James Aimers, and C. Blanchard

1992 A Preclassic Round Structure from the Zotz Group at Cahal Pech, Belize. Ms on file, Department of Anthropology, Trent University, Peterborough.

Becker, Marshall J.

1971 The Identification of a Second Plaza Plan at Tikal, Guatemala, and Its Implications for Ancient Maya Social Complexity. Unpublished Ph.D. dissertation, University of Pennsylvania, Philadelphia.

19721972 Plaza Plans at Quiriguá, Guatemala. Katunob 8(2):47-62.

Bey, George J. III, Craig A. Hanson, and William M. Ringle

1997 Classic to Postclassic at Ek Balam, Yucatán: Architectural and Ceramic Evidence for Defining the Transition. Latin American Antiquity 8(3):237-254.

Brotherson, Gordon

1976 Mesoamerican Description of Space II: Signs for Direction. Iberoamerkanisches 2(1):39-62.

Byland, Bruce E.

1993 Introduction and Commentary. In The Codex Borgia, edited by Gisele Diaz and Alan Rodgers. Dover Publications, New York.

Chase, Arlen F.

1993 Polities, Politics, and Social Dynamics: "Contextualizing" the Archaeology of the Belize Valley and Caracol. Paper presented at the 58th Annual Meeting of the Society for American Archaeology, St. Louis, MO.

Chase, Diane Z

1991 Lifeline to the Gods: Ritual Bloodletting at Santa Rita Corozal. In Sixth Round Table of Palenque, Vol. 8, edited by Virginia M. Fields, pp. 89-96. Pre-Columbian Art Research Institute, San Francisco.

Chase, Diane Z., and Arlen F. Chase

1988 Caches and Censerwares: Meaning from Maya Pottery. In A Pot for All Reasons Ceramic Ecology Revisited, edited by Charles C. Kolb and Louana M. Lackey, pp. 81-104. Laboratory of Anthropology, Temple University, Philadelphia.

1998 The Architectural Context of Caches, Burials, and Other Ritual Zctivities for the Classic Period Maya (as Reflected at Caracol, Belize). In Function and Meaning in Classic Maya Architecture, edited by Stephen D. Houston, pp. 299-332. Dumbarton Oaks, Washington, DC.

Coe, Michael D.

1965 A Model of Ancient Community Structure in the Maya Lowlands. Southwestern Journal of Anthropology 21(2):97-114.

1978 Lords of the Underworld Masterpieces of Classic Maya Ceramics. The Art Museum, Princeton University, Princeton, NJ.

Coe, William R.

1959 Piedras Negras Archaeology Artifacts, Caches, and Burials. Museum Monographs. University of Pennsylvania, Philadelphia.

Coggins, Clemency C.

1980 The Shape of Time: Some Political Implications of a Four-Part Figure. American Antiquity 45(4):727-738. on earlier drafts of this paper, and Olivia Farr for translating the abstract into Spanish.
Diaz, Gisele, and Alan Rodgers

1993 The Codex Borgia. Dover Publications, New York.

Fash, William L.

1998 Dynastic Architectural Programs: Intention and Design in Classic Maya Buildings at Copán and Other Sites. In Function and Meaning in Classic Maya Architecture, edited by Stephen D. Houston, pp. 223-270. Dumbarton Oaks, Washington, DC.

2001 Scribes, Warriors, and Kings The City of Copán and the Ancient Maya. Thames and Hudson, London.

Fedick, Scott L.

1994 Ancient Maya Agricultural Terracing in the Upper Belize River Area: Computer Modeling and the Results of Initial Field Investigations. Ancient Mesoamerica 5:107-127.

Fedick, Scott L., and Karl A. Taube

1995 The Yalahau Regional Human Ecology Project: Research Orientation and Overview of 1993 Investigations. In The View from Yalahau 1993 Archaeological Investigations in Northern Quintana Roo, Mexico, pp. 1-21. Latin American Studies Program, Field Report Series, No. 2. University of California, Riverside.

Fedick, Scott L., Dawn Reed, and Jennifer P. Mathews

1995 Road Systems. In The View from Yalahau 1993 Archaeological Investigations in Northern Quintana Roo, Mexico, edited by Scott L. Fedick and Karl A. Taube. Latin American Studies Program, Field Report Series, No. 2. University of California, Riverside.

Freidel, David A., and Linda Schele

1989 Dead Kings and Living Temples. In Word and Image in Maya Culture Explorations in Language, Writing, and Representation, edited by William F. Hanks and Don S. Rice, pp. 233-243. University of Utah Press, Salt Lake City.

Freidel, David A., Linda Schele, and Joy Parker

1993 Maya Cosmos Three Thousand Years on the Shaman's Path. William Morrow, New York.

Garber, James F., and F. Kent Reilly

1995 A Late Preclassic Mask on Structure B1 at Blackman Eddy, Cayo District, Belize. Paper presented at the First International Symposium of Maya Archaeology, San Ignacio, Belize.

Garber, James F., W. David Driver, Lauren A. Sullivan, and David M.

Glassman

1998 Bloody Bowls and Broken Pots: The Life, Death, and Rebirth of a Maya House. In The Sowing and the Dawning Termination, Dedication and Transformation in the Archaeological and Ethnographic Record of Mesoamerica, edited by Shirley B. Mock, pp. 125-133. University of New Mexico Press, Albuquerque.

Garber, James F., W. David Driver, Lauren A. Sullivan, and Sean Goldsmith 1992 The Blackman Eddy Archaeological Project Results of the 1991 Field Season. Ms on file, Department of Archaeology, Belmopan, Belize.

Garber, James F., David M. Glassman, W. David Driver, and Pamela Weiss 1994 The Belize Valley Archaeology Project Results of the 1993 Field Season. Ms on file, Department of Archaeology, Belmopan, Belize.

Gillespie, Susan D.

2000 Maya "Nested Houses": The Ritual Construction of Place. In Beyond Kinship Social and Material Reproduction in House Soci- 
eties, edited by Rosemary A. Joyce and Susan D. Gillespie, pp. 135160. University of Pennsylvania Press, Philadelphia.

Girard, Rafael

1948 Los Chortis ante el problema maya Historia de las culturas indigenas de America, desde su origin hasta hoy. 5 vols. Antiqua Libreria Robredo, Mexico City, Mexico.

1966 Los mayas Su civilization-su historia. Libro Mex, Mexico City. Glassman, David M., James M. Conlon, and James F. Garber

1995 Survey and Initial Excavations at Floral Park. In The Belize Valley Archaeology Project Results of the 1994 Field Season. Ms on file, Department of Archaeology, Belmopan, Belize.

Goldsmith, A. Sean

1993 Household Archaeology in the Belize Valley. Unpublished M.A. thesis, Department of Archaeology, University of Calgary.

Guderjan, Thomas $\mathrm{H}$.

2004 Recreating the Cosmos: Early Classic Dedicatory Caches at Blue Creek. Mesoamerican Acta, in press.

Harrison, Peter D.

1981 Some Aspects of Preconquest Settlement in Southern Quintana Roo, Mexico. In Lowland Maya Settlement Patterns, edited by Wendy Ashmore, pp. 259-286. University of New Mexico Press, Albuquerque.

Houk, Brett

1996 The Archaeology of Site Planning An Example from the Maya Site of Dos Hombres, Belize. Unpublished Ph.D. dissertation, Department of Anthropolgy, University of Texas, Austin.

Houston, Stephen D.

1998 Classic Maya Depictions of the Built Environment. In Function and Meaning in Classic Maya Architecture, edited by Stephen D. Houston, pp. 333-372. Dumbarton Oaks Research Library and Collection Washington, DC.

Jones, Christopher, and Robert J. Sharer

1980 Archaeological Investigations in the Site Core of Quiriguá. Expedition 23(1):11-19.

Joralemon, Peter D.

1976 The Olmec Dragon: A Study in Pre-Columbian Iconography. In Origins of Religious Art and Iconography in Preclassic Mesoamerica, edited by Henry B. Nicholson, pp. 27-71. UCLA Latin American Series, Vol. 31. University of California, Los Angeles.

Joyce, Rosemary A.

1992 Ideology in Action: Classic Maya Ritual Practice. In Ancient Images, Ancient Thought The Archaeology of Ideology. Proceedings of the 23rd Annual Chacmool Conference, edited by A. Sean Goldsmith, Sandra Garvie, David Selin, and Jeanette Smith, pp. 497-505. Department of Archaeology, University of Calgary.

Laporte, Juan Pedro

1991 Reconocimiento regional en el noroeste de las Montanas Mayas. Guatemala: Segundo reporte. Mexicon 13(2):30-36.

1994 Ixtonton, Dolores, Peten Entidad politica del noroeste de las Montanas Mayas. Atlas Arqueologico de Guatemala No. 2. Escuela de Historia, Universidad de San Carlos, Guatemala.

Laporte, Juan Pedro, Rolando Torres, and Bernard Hermes

1989 Ixtonton: Evolucion de un asentamiento en el Alta Mopan, Peten, Guatemala. Mayab 5:19-29.

Marcus, Joyce

1973 Territorial Organization of the Lowland Classic Maya. Science 180:911-916

1993 Ancient Maya Political Organization. In Lowland Maya Civilization in the Eighth Century A.D., edited by Jeremy A. Sabloff and John S. Henderson, pp. 111-184. Dumbarton Oaks Research Library and Collection, Washington, DC.

Mathews, Jennifer P.

1998 The Ties That Bind The Ancient Maya Interaction Spheres of the Late Preclassic and Early Classic Periods in the Northern Yucatán Peninsula. Unpublished Ph.D. dissertation, University of California, Riverside.

2001 The Road Less Traveled: Evidence for an Ancient Maya Causeway in Quintana Roo, Mexico. Paper presented at the 66th Annual Meeting of the Society for American Archaeology, New Orleans.

Mathews, Jennifer P., and Scott L. Fedick

2002 The Site of T'isil: Insight into an Average Late Preclassic Community in Quintana Roo. Paper presented at the 67th Annual Meeting of the Society for American Archaeology, Denver.
McAnany, Patricia A.

1995 Living with the Ancestors Kinship and Kingship in Ancient Maya Society. University of Texas Press, Austin.

1998 Ancestors and the Classic Maya Built Environment. In Function and Meaning in Classic Maya Architecture, edited by Stephen D. Houston, pp. 271-298. Dumbarton Oaks Research Library and Collection, Washington, DC.

McGee, R. Jon

1990 Life, Ritual, and Religion Among the Lacondon Maya. Wadsworth, Belmont, CA.

Navarette, Carlos, Maria Jose Con-Uribe, and Alejandro Martinez-Muriel 1979 Observaciones arqueologicas en Cobá, Quintana Roo. Universidad Nacional Autónoma de México, Mexico City.

Paxton, Meredith

2001 The Cosmos of the Yucatec Maya Cycles and Steps from the Madrid Codex. University of New Mexico Press, Albuquerque.

Pohl, Mary D.

1983 Maya Ritual Faunas: Vertebrate Remains from Burials, Caches, Caves, and Cenotes in the Maya Lowlands. In Civilization in the Ancient Americas Essays in Honor of Gordon R. Willey, edited by Richard M. Leventhal and Alan L. Kolata, pp. 55-103. University of New Mexico Press, Albuquerque, and Peabody Museum of Archaeology and Ethnology, Harvard University, Cambridge, MA.

Pollock, Harry E.D., Ralph L. Roys, Tatiana Proskouriakoff, and A. Ledyard Smith

1962 Mayapan, Yucatán, Mexico. Carnegie Institute of Washington Publication 619. Carnegie Institute of Washington, Washington, DC. Powis, Terry G.

1993 Special Function Structures Within Peripheral Groups in the Belize Valley: An Example from the Bedran Group at Baking Pot. In Belize Valley Archaeological Reconnaissance Report Progress of the 1992 Field Season. Ms on file, Department of Archaeology, Belmopan, Belize.

Proskouriakoff, Tatiana

1962 Civic and Religious Structures of Mayapan. In Mayapan, Yucatán, Mexico, edited by Harry E.D. Pollock, Ralph L. Roys, Tatiana Proskouriakoff, and A. Ledyard Smith, pp. 87-167. Carnegie Institute of Washington Publication 619. Washington, DC.

Redfield, Robert

1941 The Folk Culture of Yucatán. University of Chicago Press, Chicago.

Redfield, Robert, and Alfonso Villa-Rojas

1934 Chan Kom A Maya Village. Waveland Press, Prospect Heights, IL.

Reents-Budet, Dorie

1994 Painting the Maya Universe Royal Ceramics of the Classic Period. Duke University Press, Durham, NC.

Reilly, F. Kent

1990 Cosmos and Rulership: The Function of Olmec-Style Symbols in Formative Period Mesoamerica. In Visible Language, Special Edition The Emergence of Writing in Mesoamerica, Vol. XXIX, No. 1, edited by Denise Schmandt-Besserat and F. Kent Reilly III, pp. 12 41. Rhode Island School of Design, Providence.

1994 Visions to Another World Art, Shamanism, and Rulership in Middle Formative Mesoamerica. Dissertation on file, Department of Anthropology, University of Texas, Austin.

1995 Art, Ritual, and Rulership in the Olmec World. In The Olmec World Ritual and Rulership, edited by Jill Guthrie, pp. 27-44. The Art Museum, Princeton University, Princeton, NJ.

Roys, Ralph L.

1967 The Chilam Balam of Chumayel. University of Oklahoma Press, Norman.

Sanders, William T.

1955 An Archaeological Reconnaissance of Northern Quintana Roo. Carnegie Institution of Washington Report No. 24. Washington, DC

Schele, Linda, and David A. Freidel

1990 A Forest of Kings The Untold Story of the Ancient Maya. William Morrow, New York.

Schele, Linda, and Peter Mathews

1999 The Code of Kings The Language of Seven Sacred Maya Temples and Tombs. Simon and Schuster, New York.

Schele, Linda, and Mary Ellen Miller

1986 The Blood of Kings Dynasty and Ritual in Maya Art. Kimball Art Museum, Fort Worth, TX. 
Scholes, France V., and Ralph L. Roys

1938 Fray Diego de Landa and the Problem of Idolatry in Yucatán. In Cooperation in Research, pp. 585-620. Carnegie Institute of Washington Publication 501. Carnegie Institute of Washington, Washington, DC.

Seler, Eduard

1901-1902 Codex Fejervary-Mayer An Old Mexican Picture Manuscript in the Liverpool Free Public Museum. T. and A. Constable, Edinburgh.

Sharer, Robert J., Loa P. Traxler, David W. Sedat, Ellen E. Bell, Marcello

A. Canuto, and C. Powell

1999 Early Classic Architecture Beneath the Copán Acropolis: A Research Update. Ancient Mesoamerica 10:3-23.

Smith, A. Ledyard

1950 Uaxactun, Guatemala Excavation of 1931-1937. Carnegie Institute of Washington Publication 588. Carnegie Institute of Washington, Washington, DC.

1972 Excavations at Altar de Sacrificios Architecture, Settlement, Burials, and Caches. Peabody Papers, Vol. 62, No. 2. Peabody Museum of Archaeology and Ethnology, Harvard University, Cambridge, MA.

Taube, Karl A.

1993 Aztec and Maya Myths. University of Texas Press, Austin.

1996 The Olmec Maize God: The Face of Corn in Formative Mesoamerica. RES Anthropology and Aesthetics 29-30:39-81.

Tedlock, Barbara

1982 Time and the Highland Maya. University of New Mexico Press, Albuquerque.

Tedlock, Dennis

1985 Popol Vuh The Mayan Book of the Dawn of Life. Simon and Schuster, New York.
Thompson, J. Eric S.

1930 Ethnology of the Mayas of Southern and Central British Honduras. Field Museum of Natural History Publication 274, Anthropological Series Vol. XVII, No. 2. Chicago.

1966 The Rise and Fall of Maya Civilization. University of Oklahoma Press, Norman.

1970 Maya History and Religion. University of Oklahoma Press, Norman.

Tourtellot, Gair

1988 Excavations at Seibal Peripheral Survey and Excavation, Settlement and Community Patterns. Memoirs of the Peabody Museum of Archaeology and Ethnology, Vol. 16. Harvard University, Cambridge, MA.

Tozzer, Alfred M. (editor)

1966 Landa's Relación de las Cosas de Yucatán A Translation. Papers of the Peabody Museum of American Archaeology and Ethnology, Vol. 18. Harvard University, Cambridge, MA.

Villacorta, J. Antonio, and Carol A. Villacorta

1930 Codices Maya. Tipografica Nacional, Guatemala City.

Vogt, Evon Z.

1976 Tortillas for the Gods A Symbolic Analysis of Zinacanteco Rituals. University of Oklahoma Press, Norman.

Von Hagen, Victor W.

1960 The World of the Maya. New American Library, New York.

Willey, Gordon R., William R. Bullard, Jr., John B. Glass, and James C. Gifford

1965 Prehistoric Settlements in the Belize Valley. Papers of the Peabody Museum of Archaeology and Ethnology, Vol. LIV. Harvard University, Cambridge, MA.

Wisdom, Charles

1940 The Chorti Indians of Guatemala. University of Chicago Press, Chicago. 